\title{
To Seek Revenge or to Forgive: Two Chinese films
} about Hamlet

Hui Wu

\section{(2) OpenEdition}

1 Journals

\section{Electronic version}

URL: http://journals.openedition.org/shakespeare/1517

DOI: 10.4000/shakespeare. 1517

ISSN: 2271-6424

Publisher

Société Française Shakespeare

Printed version

Date of publication: 13 December 2009

Number of pages: 189-197

ISBN: 2-9521475-6-6

\section{Electronic reference}

Hui Wu, «To Seek Revenge or to Forgive: Two Chinese films about Hamlet », Actes des congrès de la Société française Shakespeare [Online], 27 | 2009, Online since 13 December 2009, connection on 19 April 2019. URL : http://journals.openedition.org/shakespeare/1517 ; DOI : 10.4000/

shakespeare.1517 


\title{
Shakespeare et l'Orient
}

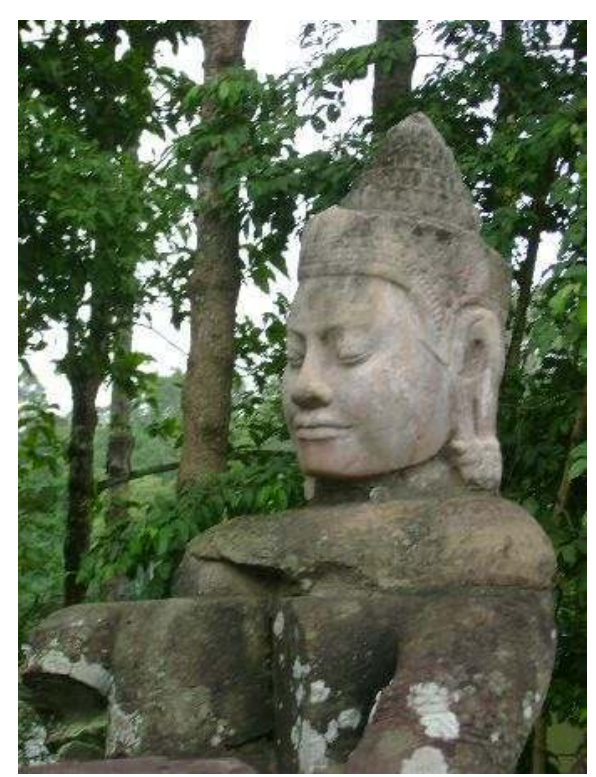

\author{
actes du Congrès \\ organisé par la \\ les 12, 13 et 14 mars 2009 \\ textes réunis par \\ Pierre KAPITANIAK \\ sous la direction de \\ Jean-Michel DÉPRATS
}

SOCIÉTÉ FRANÇAISE SHAKESPEARE 
COUVERTURE :

photo J.-M. Déprats 2008

conception graphique et logo

Pierre Kapitaniak

\section{(C) 2009 Société Française Shakespeare \\ Institut du Monde Anglophone \\ Université de Paris III - Sorbonne Nouvelle \\ 5 rue de l'École de Médecine 75006 Paris \\ www.societefrancaiseshakespeare.org}




\section{To SEeK REVENGE OR TO Forgive: TWO CHINESE FILMS ABOUT H AMLET}

In 2006, two Chinese adaptations of Hamlet were released almost simultaneously: The Banquet by Feng Xiaogang and Prince of the Himalayas by Hu Xue-hua. While The Banquet is situated in a Chinese imperial palace, Prince of the Himalayas takes place in the Tibetan Highlands. Both films can serve as excellent examples of the art of adaptation, though their style is totally different.

En 2006, deux adaptations chinoises de Hamlet sont sorties presque simultanément: Le banquet de Feng Xiao-gang et Le prince des Himalayas par Hu Xue-hua. Alors que Le banquet se situe dans un palais de la Chine impériale, Le prince des Himalayas se passe dans les hautes terres du Tibet. Les deux films peuvent servir d'exemples de l'art de l'adaptation, bien que leur style soit totalement différent.

I

$\mathrm{n}$ the history of Shakespeare adaptations on film, there have been many Hamlet versions, such as the British Hamlet by Laurence Olivier in 1948, the Russian Hamlet by Grigori Kozintsev in 1964, the British-Italian Hamlet by Franco Zeffirelli in 1990, the British Hamlet by Kenneth Branagh in 1996 and the American Hamlet by Michael Almereyda in 2000.

However, the first Chinese versions did not appear until 2006. First, there was The Banquet by Feng Xiao-gang. Shortly after that, followed Hu Xue-hua's Prince of the Himalayas. The Banquet was a blockbuster in China and a box-office success, but received widespread criticism for its commercial aesthetics. By comparison, Prince of the Himalayas raised attention amongst academics and critics and won several prizes at film festivals in Morocco, Italy and the U.S. It has even been nominated for the Golden Globe, but was not so successful in the cinemas. Both films were inspired by Hamlet, but they are totally different in story, character, picture, music and style.

\section{Different plots}

The Banquet is a typical Chinese palace-struggle tragedy. It takes place in the late Tang dynasty in $907 \mathrm{AD}$, when a prosperous period was followed by turmoil. Prince Wu Luan (Hamlet) and the young girl Little Wan (Gertrude) were lovers from their childhood. But when Little Wan grew up, her lover's father, the old emperor, married her himself. Later 
on, the new emperor Li (Claudius), who has murdered his elder brother, marries her in his turn. While empress Wan is getting physical satisfaction from her new husband, she still loves the prince and protects him from the new emperor - his uncle, who wants to kill him. Eventually, Li finds a way to get rid of his potential rival for power and love. Believing that the prince is dead, he holds a big banquet to celebrate what he thinks is his ultimate triumph.
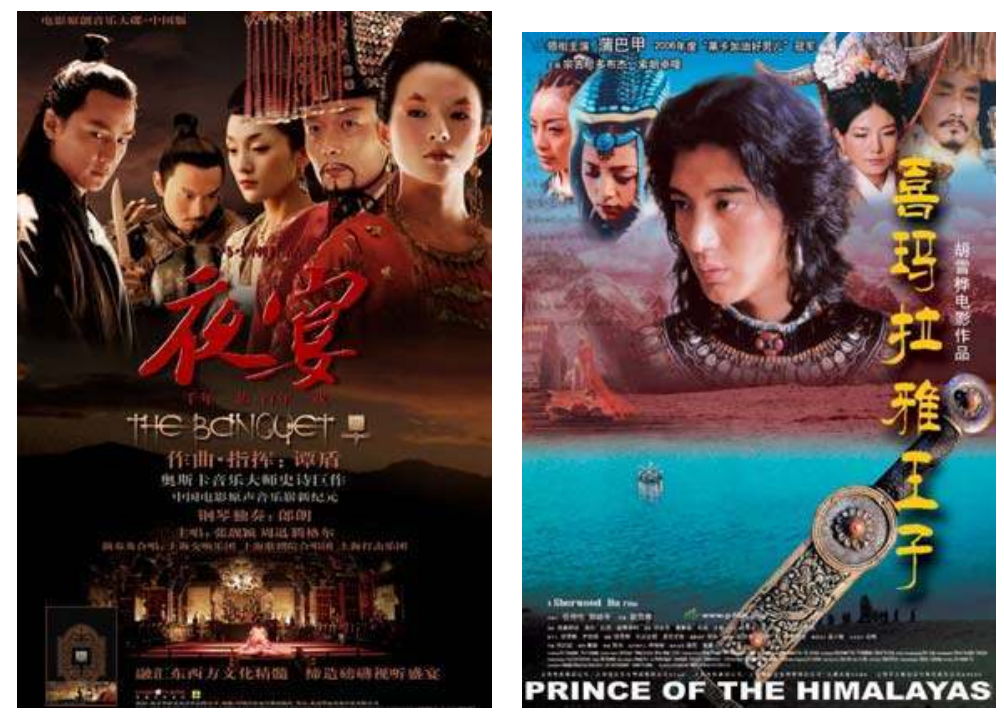

But it will end in a catastrophe. Empress Wan intends to poison the emperor with a glass of wine and then to seize the throne. But instead, Qing Nü (Ophelia), who has loved the prince secretly all along, drinks the wine by accident. Only then does the prince uncover himself - his life has been saved by general Yin Sun (Laertes), Qing Nü's brother. Realizing that the empress has never loved him, the emperor kills himself by drinking the poisonous wine on purpose. Then, prince $\mathrm{Wu}$ Luan dies after touching a poisoned sword, again by accident. Finally, empress Wan becomes the ruler, but soon after that, she is stabbed by an unknown dagger-man.

Prince of the Himalayas tells an ancient tribal tragedy which takes place in the western highlands of today's Tibet. Actually, the beautiful queen (Gertrude) and Kulo-ngam (Claudius), the king's younger brother, have loved each other for a long time. But the king 
takes her away from his brother and marries her. When he finds out that his wife is still thinking of her lover and, moreover, that prince Lhamoklodam (Hamlet) is not his son, but Kulo-ngam's, the king conspires to kill both of them. To save the lives of the queen and the prince, Kulo-ngam kills the king. After that, he becomes the new king and marries the queen.

The funeral and the wedding are held at the same time. Prince Lhamoklodam becomes the Himalayan Hamlet. The ghost of the dead king asks him to take revenge, while a wolf-woman (a positive character, invented for the film) asks him to forgive. After discovering the whole secret, Lhamoklodam neither obeys the ghost nor the wolfwoman. He would rather die than suffer in this world. Finally he is killed by a poisoned sword in the duel, but for the first and also the last time, he calls Kulo-ngam "my father" at the end. The queen drinks the poisoned wine and dies as well. After saying "Let us be reunited in heaven!” Kulo-ngam eventually kills himself with his sword.

\section{Different characters}

In The Banquet, the empress becomes a leading character, played by Zhang Zi-yi, a Chinese movie star. She has a close relationship with three men. The first one, whom she is forced to marry, is much older than she is. He does not make her happy, but makes an empress out of her. The second one, whom she has to marry because of fear and selfprotection, is a murderer, but loves her deeply and even dies to fulfil her wishes. The third one, whom she really loves and wants to marry and support, is a prince who then becomes her "son". Empress Wan is an ambitious woman with a strong will, experiencing constant conflicts between love and power. Eventually, she is disappointed by her lover and brave enough to challenge her destiny, but is finally destroyed by her desires.

By comparison, Prince Wu Luan is never interested in power and is even sickened by it. Instead, he wants to become a great artist a singer and a dancer. In order to avoid the cruel and ugly reality, he becomes obsessed with classical Chinese music and dance. He loves Little Wan more than empress Wan, because their personalities and life values become more and more different. Here are a few lines of their dialogue as an example: 
EMPRESS WAN. Why do you wear a mask when you perform?

PRINCE WU LUAN. It transports an actor to the highest state of his art. Without a mask, happiness, anger, sorrow and joy are simply written on his face, but with a mask, a great artist can convey to the audience the most complex and hidden emotions.

EMPRESS WAN. In that case, what do you see in my simple face?

PRINCE WU LUAN. Six parts arrogance, three parts disquiet and one part guilt towards your late husband.

EMPRESS WAN. You are wrong. It is disappointment [...) disappointment in you. I no longer look to you to fulfil my dreams [...] You are incapable of even the most basic play-acting. Your sorrow, anger, bitterness and uncertainty are there for all to see [...] You think hiding behind a mask can elevate your art. The highest level is to use your own face and turn it into a mask. $\quad$ (T.C. oo:52:18)

It is clear that empress Wan knows well how to survive deceitfully in the palace-struggle. On the contrary, as an introverted artist with a pessimistic and melancholic character, $\mathrm{Wu}$ Luan is too weak to take revenge, and is even suspicious of it. When dying in his lover's arms, his last words are: "How good it is to die!"

In Prince of the Himalayas, there are actually two princes. The first one, Lhamoklodam, is the son of the queen and of her lover Kulongam. His fundamental question is not "to be or not to be", but whether to seek revenge or to forgive. He is brave enough to take action. However, the man he wants to kill turns out to be his real father. At last, he yearns to die and departs for heaven with strong religious beliefs, whereas Prince $\mathrm{Wu}$ Luan in The Banquet longs for death because of his nihilism. The second prince in the Tibetan film is the son of Lhamoklodam and of his lover Odsaluyang (Ophelia), who gives birth in the river and then dies. The baby is saved by the wolfwoman, a character created by the filmmaker ${ }^{1}$. In the last moments of Lhamoklodam's life, the boy is put in his arms - he is the new Prince of the Himalayas.

Kulo-ngam is the new king of the Jiabo tribe in the remote and majestic highlands. He is the equivalent of Claudius, but quite different from any other version of Hamlet. He kills the king, not for the throne, but to protect his lover and their son. His consciousness makes him suffer a lot from the murder of his brother and the secret about his son. As a thoughtful and responsible man, Kulo-ngam remains silent to

\footnotetext{
${ }^{1}$ She looks like an elderly lady with grey hair and is in fact a spiritual being between earth and heaven, acting as a narrator to tell the truth. Thus, she is opposed to the dead king's ghost as a positive force and teaches the prince to love and not to take revenge.
} 
endure all the sufferings by himself. He is a good husband and father, and not a bad king. That so many kind people have to pay the prices for their love is the real tragedy in the film.

\section{Different pictures}

The Banquet is dominated by three colours: red, black and white. Red symbolises the empress's desires; black represents emperor Li's evil character; and white stands for the prince's innocence and purity. Occasionally, some dark green means life and love, which expresses Qing Nü's good wishes. For instance, the last shot of the film shows the green leaves on the surface of water in a vase, and then the dagger with the blood of the empress is thrown into it.

The images of the palace enclosed within high and heavy walls and the ceremonies held in it show the sense of worship associated with royal power. The cameras quite often shoot from a bird's eye view, so that the people in the palace seem to live in a deep and cold well, though the decoration is elegant and luxurious. All this gives us an impressive example of ancient Chinese civilisation. The light effect is usually sombre and gloomy, evoking a rather depressing mood and creating a romantic but tragic atmosphere.

Prince of the Himalayas takes us to an even more exotic environment. Instead of the state of Denmark, something is 'rotten' in the kingdom of Jiabo. We plunge into an archaic world, brought to life by Tibetan professional and non-professional actors in their own costume and language. Most of the film takes place on location with strong light, bright colours, wide views and angles. While Feng Xiaogang identifies China with ancient civilisation, Hu Xue-hua identifies Tibet with glorious nature. We witness not only its beautiful sceneries with high snowy mountains and crystal-clear lakes, but also its traditional rituals such as heaven's burial, fire and water burial. People seem to live there in harmony with nature. In such a pure environment, noble thoughts can thrive.

\section{Different music}

Music plays an important role in both films. Tan Dun, a world-class musician, is the composer of The Banquet's musical score. The prince 
in the film is himself both a dancer and a singer. He is especially keen on a rather sad and sentimental Yue Ren Song, a type based on a love legend from ancient times. So does his lover, who expresses her feelings through the same song:

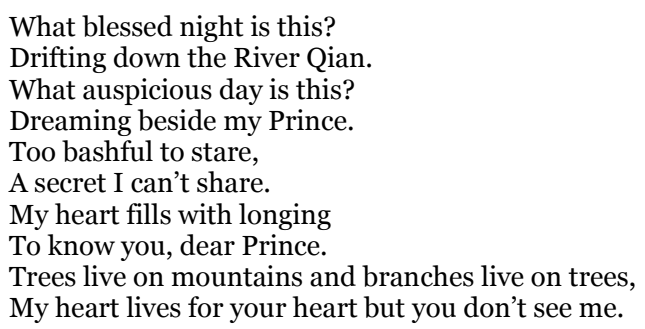

My heart lives for your heart but you don't see me.

(T.C. 01:42:10)

While the old Yue Ren Song had a happy ending, the Prince's end is tragic. Its sorrowful melody, which is played on traditional Chinese instruments such as Pipa and Guzheng ${ }^{2}$, keeps echoing in the palace. However, Feng Xiao-gang also uses a modern song with a popular melody to summarize the tragedies at the end of the film, as most of TV dramas do.

The music for Prince of the Himalayas has been written by $\mathrm{He}$ Xun-tian, a professor at the Shanghai Conservatory and also a distinguished composer. He uses traditional Tibetan music from monasteries, such as bass drum and horn, often used for religious rituals, evoking archaic and spiritual spheres. They sound very stirring and exciting with their low and deep voices which reverberate on the Tibetan plateau. The theme song Holy Incense with Buddhist incantations has even been called a "song from heaven" by some enthusiasts:

\footnotetext{
A sea of faces

Hong-ma-ni-bei-bei-hong

[ = Om mani padme hum]

But I cannot see my lover

He is gone

Hong-ma-ni-bei-bei-hong...
}

(T.C. oo:12:30)

\footnotetext{
2 The Pipa, a traditional folk instrument, is sometimes called "the Chinese lute". It has four strings and a special timbre, with its range wide enough to play all half-scales. Guzheng is an ancient plucked instrument with 21 or 25 strings. It produces a very elegant and graceful sound.
} 
Singer Sa Ding-ding has been selected as "the Best Asian Singer" for the "2008 BBC World Music Award". The music is lyrical and dynamic, particularly in the love and duel scenes. Besides heavy instruments such as Tibetan drums and trombones, He Xun-tian also uses electronic music, but based on ancient tunes.

\section{Different directors}

The personalities of both directors are very different. Feng Xiao-gang, a typical Beijing citizen born 1958, comes from an ordinary background. He studied stage design and later on became a successful movie director. He has shot more than ten films and TV dramas, mainly comedies about common people, done in a realistic style with witty dialogues. The Banquet is his first adaptation from a classical play. Having been successful in mainstream entertainment, he wanted to succeed as a "real artist" as well.

$\mathrm{Hu}$ Xue-hua (Sherwood Hu), born 1961, comes from a family of dramatists in Shanghai. He studied theatre both in China and America. Having lived in the U.S. for twenty years, he is, of course, very fond of Shakespeare. And so was his father. $\mathrm{Hu}$ is familiar with Western culture and theatre tradition. He wanted to make a film which nobody had made before, for both Western and Eastern audiences. He deliberately selected Tibet as the location, a place where spiritual needs still seem more important than material ones. Prince of the Himalayas is his fourth film ${ }^{3}$. He directed it, but also wrote and produced it.

\section{Different similarities}

Both adaptations not only transferred Shakespeare's play from stage to screen, but also from Europe to East Asia. Both of them considerably changed the story, particularly when it comes to the question of justice and revenge. Though there are a thousand Hamlets in a thousand people's minds, the inner logic of most adaptations has never changed. The creativity of both The Banquet and The Prince is that they modify the traditional plot by rewriting the play's structure and the relations

3 His previous films are King Lanling (1994), Lani-Loa: The Passage (1998) and On The Roof (2001). King Lanling won the "Best Picture award" of SCIFF (1995). 
between the protagonists. Both films are essentially psychological studies. The Banquet puts the emphasis on the negative feelings and tempting power, whereas Prince of the Himalayas eventually overcomes hatred and teaches love.

Both films are poetic. They introduce us to a foreign world, full of colours, exotic details and mysteries. The Banquet resembles a classical Chinese poem; notably when Prince Wu Luan sings his Yue Ren Song in a bamboo forest, slowly dancing in a white robe and mask. Prince of the Himalayas seems more like a national epic with grand narration and heroic myths. Both films had a big budget - fourteen and twenty million U.S.-dollar respectively - and were meant to become commercial and international successes.

In East Asian cultures, the inner struggle is traditionally more important than the fight against external forces. Both films clearly reflect Chinese moral philosophy and Confucian principles. For example, in Chinese tradition (as in Europe), it is unthinkable that a son should openly fall in love with his mother, or a man with his sisterin-law. Therefore, the authors and directors had to find other explanations for the strange behaviour of the protagonists. So they used the motive of 'eternal love' from childhood on to the very end, which is common in classical Chinese literature. Both of them rather neglect the old emperor's and the king's 'love' for the empress and the queen, putting the emphasis on other relationships. Director Feng, for example, deliberately chose a woman as the leading character to tell the story from an unusual perspective. In feudal society, women hardly ever gained power or got involved in political matters. In a men's world, empress Wan can only have a tragic end.

In ancient Western tragedy, the hero dies physically, while his noble virtues are glorified. The Eastern concept of afterlife, deeply influenced by Buddhist philosophy, is different. No matter who dies there is always hope that he or she might return in another form. For example, Lhamoklodam, the Himalayan Hamlet, decides to die instead of obeying the will of the dead king. In return, the baby prince is born, the son of Lhamoklodam and his mistress. A typical Eastern concept of tragedy: instead of ultimate death, we see rebirth, hope and the return of life. When Shakespeare's Hamlet dies, the curtain falls. In the Himalaya, his son is born, life is an endless circle, and love is eternal. 
It is not just by coincidence that both films appear right now. Chinese economy has developed rapidly, and so has its movie industry. The film-makers' ideas about movies, culture and society have dramatically changed since the so-called "Fifth Generation" first received international attention in the 1980s. Chinese contemporary filmmakers want their films not only to be successful in art, but also commercially. As the Chinese saying goes, both Hamlet adaptations "make foreign things serve China and make the past serve the present".

Hui Wu

Communication University of China, Beijing 